\title{
PELAYANAN TERHADAP JEMAAT LANJUT USIA SEBAGAI PENGEMBANGGAN PELAYANAN KATEGORIAL
}

\author{
Elvin Paende
}

\section{PENDAHULUAN}

Lanjut usia adalah orang yang sudah memasuki usia tahap akhir dalam rentang kehidupannya dimana ia meninggalkan masa yang penuh dengan manfaat dan masa yang menyenangkan. Kenyataan ini tidak dapat dihindari oleh siapapun dalam perjalanan hidupnya.Hasil sensus penduduk tahun 1990 menunjukkan bahwa pada tahun 1971, jumlah lanjut usia 5,3 juta atau 4,5\% dari seluruh penduduk Indonesia. Pada tahun 1980 jumlah lanjut usia meningkat menjadi 11,3 juta jiwa $(6,4 \%)$. ${ }^{1}$ Lebih lanjut dikatakan bahwa pada tahun 2005-2010 diperkirakan jumlah lanjut usia akan sama dengan jumlah anak balita yang mencapai sekitar 19 juta jiwa (8,5\% dari jumlah seluruh penduduk). Namun, setelah tahun 2010 jumlah lanjut usia akan melebihi jumlah anak balita. ${ }^{2}$ Juga dikatakan bahwa manusia lanjut usia dalam sepuluh tahun mendatang akan menduduki jumlah yang lebih banyak jika dibandingkan dengan anak-anak, remaja atau usia produktif. ${ }^{3}$

Dengan meningkatnya harapan hidup, para lanjut usia juga diperhadapkan dengan permasalahan-permasalahan yang cukup rumit. Oleh karena itu makin lanjut usia seseorang, makin banyak kemunduran yang terjadi, terutama kemampuan fisik yang mengakibatkan berkurangnya peranan sosial. ${ }^{4}$ Disamping itu, S.M. Lumbantobing mengemukakan bahwa:

Pada manusia lanjut usia (manula, usia di atas 60 tahun) sering dijumpai berbagai gangguan kecerdasan (kognitif), gangguan fungsi gerak dan rasa serta gangguang keseimbangan dan koordinansi. Orang lanjut usia banyak menurun sifat kehangatannya serta berkurang spontanitasnya terhadap orang lain. ${ }^{5}$

1 Peranan Pemerintah Dalam Pembinaan Kesejahteraan Sosial Lanjut Usia (Jakarta: Departemen Sosial RI, 1999), hlm. 1

2 Pelembagaan Lanjut Usia Dalam Kehidupan Bangsa, (Jakarta: Departemen Sosial RI, 1998), hlm. 6.

3 Edi Soetodjo, “Jangan Menjadikan Lanjut Usia Seperti Tong Sampah", Suara Pembaharuan (Jakarta), 17 Juli 1994, hlm. 12. Kol. 7.

4 Pelembagaan Lanjut..., hlm. 12.

5 S. M. LumbanTobing, Kecerdasan Pada Usia Lanjut dan Manusia (Jakarta:Balai Penerbit FKUI, 1995), hlm. 1. 
Dengan demikian kondisi di atas antara lain: pertama, kekerabatan semakin bergeser sehingga lanjut usia kurang dihargai, dihormati dan diperhatikan karena pola hidup keluarga mengarah pada bentuk keluarga kecil. ${ }^{6} \mathrm{Kedua}$, para lanjut usia menjadi bergantung pada orang lain secara fisik. Ketiga, adanya kesenjangan antara generasi tua dan generasi muda. ${ }^{7} \mathrm{Hal}-\mathrm{hal}$ ini dapat menimbulkan masalah yang lebih serius terhadap para lanjut usia seperti, depresi, stres, atau kecemasan (anxetas). ${ }^{8}$

\section{PEMAHAMAN UMUM \\ TENTANG KEHIDUPAN LANJUT USIA}

\section{Pengertian Umum Tentang Lanjut Usia}

\section{Etimologi}

Masa tua adalah suatu tahap yang merupakan tahap akhir dari akhir siklus kehidupan dan perkembangan normal pada setiap orang. Sebutan bagi mereka yang sudah memasuki masa tua umumnya ialah lanjut usia mereka rata-rata telah memasuki usia (lansia), pada umumnya usia mereka rata-rata telah memasuki usia 60 tahun ke atas. Walaupun demikian, batasan "lanjut usia" sendiri memiliki kriteria yang berbeda bergantung pada sudut pandang masing-masing orang, seperti yang dikatakan Sasanto Wibisono sebagai berikut:

'Usia Lanjut' bukanlah satu pengertian ilmiah. Berbagai kalanga/ahli menggunakan kriteria batas usia lanjut yang berbeda-beda, tergantung dari segi life expectancy, dari segi fungsi sosial, ataukah dari segi fungsi sosial, ataukah dari segi fungsi biologis, dan sebagainya. ${ }^{9}$

Dalam studi gerontologi, yaitu suatu cabang ilmu pengetahuan tentang proses menjadi tua dan masalah yang dihadapi lanjut usia, batasan umur lanjut usia dibagi dalam empat kelompok yaitu: usia 45-59 tahun, termasuk dalam kategori wredo madya; usia 60-74 tahun, disebut sebagai wreda utama; usia 74-90 tahun, sebagai wreda prawana sedangkan 90 tahun keatas digolongkan sebagai usia. Akan tetapi orang sering menyadari bahwa usia menurut urutan waktu merupakan kriteria yang kurang baik dalam menandai permulaan lanjut usia, karena terdapat perbedaan tertentu di antara indivi-individu dalam usia

\footnotetext{
6 Pelembagaan Lanjut..., hlm. 10-11.

7 Petunujuk Teknik Pelaksanaan Pelayanan Kesejahteraan Sosial Lanjut Usia Dalam Panti (Jakarta: Departemen Sosial RI, 1997), hlm. 1.

8 “Masalah Kualita Hidup Manula", Suara Pembaharuan, (Jakarta), 1989.

9 Sasanto Wibisono, "Pengaruh Perubahan Fisik Usia Lanjut Pada Aspek Kejiwaan”, dalam Mardiono Marsetio, Arjatmo Tjokronegoro, ed., Kelanggengan Usia Lanjut (Jakarta: Fakultas Kedokteran Universitas Indonesia, 1991), hlm. 1
} 
saat mana lanjut usia mereka mulai. ${ }^{10}$ Dengan demikian memahami pengertian umum tentang lanjut usia, akan sangat menolong dalam memulai suatu pelayanan terhadap mereka.

\section{Fase Perkembangan}

Sebenarnya para lanjut usia telah melewati beberapa masa krisis dalam hidup mereka. Karena setiap orang telah dikondisikan dalam beberapa tahap/fase yang tidak mungkin dihindari. Beberapa fase/tahap perkembangan tersebut dapat dijelaskan sebagai berikut:

Pertama, masa bayi yaitu masa di antara 2 minggu sampai 2 tahun. pada masa ini semua orang belum mampu melakukan segala sesuatu untuk diri sendiri, sehingga dikatakan bahwa masa bayi merupakan masa ketergantungan, masa ketidakberdayaan yang membutuhkan pertolongan dari orang lain. ${ }^{11}$

Kedua, masa kanak-kanak yaitu antara usia 2 tahun sampai 10/11 tahun. pada masa ini setiap orang masih immature (belum matang). Selaku anak-anak pada masa ini adalah masa menyesuikan diri dengan linkungan. Setiap anak merasa bahwa dirinya merupakan bagian dari linkungan yang ada. Terkadang mereka mengidentifikasikan dirinya dengan linkungan sekitarnya. ${ }^{12}$

Ketiga, masa remaja yaitu masa transisi dari anak-anak ke masa dewasa. Dalam masa remaja setiap orang diperhadapkan dengan masa krisis terus-menerus, tetapi juga masa yang penuh dengan pengalaman yang menegangkan, masa stres dan badai. Remaja juga mengalami perasaan yang meragukan diri sendiri, rasa rendah diri dan tekanan sosial yang memuncak. Bahkan dikatakan, harga diri seorang remaja ditentukan oleh teman-teman sebaya. $^{13}$

Keempat, Masa dewasa, yaitu masa yang merupakan kelanjutan dari masa yang merupakan kelanjutan dari masa remaja. ${ }^{14}$ Masa dewasa ini terbagi lagi atas beberapa tahap sebagai berikut:

1) Dewasa awal (21-40 tahun). dalam masa ini seseorang tidak lagi memerlukan asuhan dan bergantung pada orang tua. Mereka sudah dapat menerima dan memeberi dorongan kepada orang lain. Dalam masa ini setiap orang telah memiliki sistem nilai sehingga tidak memerlukan tuntunan orang tua lagi.

2) Masa dewasa menengah (40-60 tahun). Usia dewasa menengah adalah suatu masa transisi dari tahap dewasa awal ke tahap dewasa lanjut. Masa ini merupakan tahap yang ditakuti sebagian orang. Oleh karena

10 F. Hamma SJ, Krisis Tengah Umur (Yogyakarta: Penerbit Kanisius, 1988), hlm. 10.

11 Janus Kenny, Mory Kenny, Dari Bayi Sampai Dewasa (Jakarta: BPK. Gunung Mulia, 1991), hlm. 151

12 Saparinah Sadli, Di Atas 40 Tahun (Jakarta: Sinar Harapan, 1983), hlm. 66

13 H. Norman Wright, Konseling Krisis (Malang: Gandum Mas, 1993), hlm. 198

14 Andi Mappriare, Psikologi Orang Dewasa (Surabaya: Usaha Nasional, 1983), hlm. 
pada usia ini terjadi perubahan fisik dan ketakutan mental mulai menurun. $^{15}$

3) Masa dewasa lanjut usia (60 tahun ke atas). Pada tahap ini setiap orang mengalami kemunduran diri dari tahun-tahun kreatif dan mereka diperhadapkan pada kemunduran-kemunduran fisik dan mental. ${ }^{16}$

Sebenarnya masa lanjut usia merupakan suatu tahap kematangan pribadi dan kaya akan pengalaman yang didapat selamaperjalanan hidup seseorang. Pengalaman tersebut dapat disumbangkan bagi masyarakat disekitarnya. Hal ini juga dikemukakan oleh S. M. Herlambang dalam Forum Komunikasi Lansia sebagai berikut:

Pada dasarnya lanjut usia adalah orang-orang yang sudah memang dalam mengatasi krisis demi krisis yang dihadapi dalam kehidupannya. Karena itu mereka dapat dijadikan mitra dalam memecahkan problem nasional, karena ketrampilan dan pengalaman serta dedikasinya tidak kalah dengan generasi muda. ${ }^{17}$

Pada sisi lain dikatakan bahwa dalam kehidupan keluarga, lanjut usia merupakan figur tersendiri dalam kaitan dengan sosial budaya bangsa, sedangkan dalam kehidupan nasional, mereka adalah sumber daya manusia yang cukup berpotesi sesuai pengetahuan dan pengalaman hidupnya untuk meningkatkan mutu kehidupan masyarakat. ${ }^{18}$ Pada umumnya para lanjut usia sudah mengalami kemunduran secara fisik sehingga mereka tidak dapat menyumbangkan kekuatan dan tenaganya dalam melakukan pekerjaan untuk orang lain, tetapi mereka memiliki kekayaan pengalaman yang tidak sedikit di mana dapat disumbangkan kepada orang lain dalam kapasitas pribadi maupun kepentingan umum.

\section{Perubahan-PerubahanYang Terjadi Pada Lanjut Usia}

\section{Perubahan Fisik}

Secara biologis setiap manusia mencapai puncak perkembangan ketika seseorang mencapai usia dewasa. Setelah itu, tumbuh manusia mengalami perubahan yang mengarah pada penurunan. ${ }^{19}$ Creath Davis Mengatakan bahwa:

15 Mapriare, Psikologi Orang ..., 71

16 Sadli, Di atas 40 ..,hlm. 71

17 S. M. Herlambang, "Forum Komunikasi Lansia/ Pergeri” Dimasa Depan, "Buletin Gerontologi dan Geriatri XXXI XXXII” (1997), 28.

18 Suenarjo, "Usia Lanjut Usia Sehat Sejahtera dan Bermamfaat," Buletin Gerontologi dan Geriatri, XXXI-XXXII (1997), 43

19 Hamma, Krisis Tengah ..., 23 
Proses menua merupakan penurunan secara sedikit demi sedikit, di mana sekitar umur tiga puluh kita tidaklah muda pada suatu hari dan menjadi tua pada hari berikutnya.

Pada umumnya tanda-tanda ketuaan pada lanjut usia dapat dilihat melalui penampilan seperti menurunnya fungsi tubuh, daya tolak penyakit menurun, penglihatan berkurang, perubahan pada rambut yaitu mulai memutih dan menipis, kulit pada wajah, tengkuk, lengan dan tangan menjadi kasar dan berkerut. Kemudian perubahan fisik lain yang berubah ialah bagian dalam tubuh. ${ }^{20} \mathrm{Jadi}$, perubahan fisik bukan hanya pada sebagian tubuh lanjut usia, tetapi terjadi perubahan pada seluruh bagian tubuh baik yang dapat dilihat maupun yang terdapat dalam tubuh itu sendiri.

\section{Perubahan Psikologis}

Setiap manusia pasarnya adalah mahkluk sosial yang menjadi manusia karena ada orang lain. Karena itu dalam perkembangan dan pertumbuhannya, sangat membutuhkan orang lain. Sikum Pribadi mengatakan bahwa:

Pengaruh di bidang kejiwaan umumnya merupakan 'manifestasi' ketidak keberhasilan adaptasi terhadap berbagai perubahan tersebut. Dampak di bidang ke jiwaan dapat berupa berbagai bentuk gangguan penyesuian, depresi, gangguan somatisasi, gangguan perubahan kulit, raut muka, rambut dan perubahan penampilan lainnya secara keseluruhan dapat menimbulkan berbagai pengaruh psikis, rasa rendah diri, perasaan asing, kehilangan kepercayaan diri, depresi dan lainlain. $^{21}$

Dengan demikian mau tidak mau akan terjadi perubahan psikologis dalam kehidupan lanjut usia. Perubahan psikologis ini akan menjadi masalah atau pergumulan para lanjut usia jika mereka tidak mampu atau gagal menyesuikan diri dengan berbagai perubahan fisik yang harus dialaminya.

\section{Perubahan Sosiologis}

Setiap manusia pada dasarnya adalah mahkluk sosial yang menjadi manusia karena ada orang lain. Karena itu dalam perkembangan dan pertumbuhannya, sangat membutuhkan orang lain. Sikun pribadi mengatakan bahwa:

Sebagai mahkluk sosial ia mempunyai hubungan dengan orang lain baik langsung maupun tidak lansung, baik itu hubungan positif maupun negatif ataupun permusuhan (konflik). Karena adanya orang lain maka

20 R. K. M. Suling dan S. S. Pelenkahu, Pedoman Praktis bagi Manusia Usia Lanjut (Jakarta: BPK Gunung Mulia, 1996), hlm. 31-32

21 Wibisono, "Pengaruh Perubahan ..." 7 
manusia mempunyai kesadaran "aku"nya. dia menilai diri-sendiri tidak lepas dari penilaian lingkungan terhadap dirinya. ${ }^{22}$

Disamping itu, banyak lanjut usia yang mengalami "post power sindroma." Mereka merasa masih menduduki keputusan, mengatur dan memimpin. Hal ini terjadi karena tidak menyadari ada perubahan dalam lingkungan. ${ }^{23}$ Oleh karena itu para lanjut usia mengalami masalah dalam menempatkan diri (adaptasi) di lingkungan rumah tangga maupun lingkungannya tanpa embel-embel yang ditonjolkan selama ini.

\section{Perubahan Spiritualitas}

Perubahan spiritualitas ini ditandai dengan adanya perubahan minat dan sikap terhadap kegiatan keagamaan. Hal ini terjadi karena mereka melihat banyak teman sebayanya yang sudah meninggal dunia. Hal ini mereka termotivasi untuk tertarik dan menekuni kegiatan keagamaan. Pendeta Agus Wijanto mengatakan:

Dalam pengamatan selama melayani jemaat lanjut usia, ternyata bahwa semakin tua seseorang semakin serius dalam kerohanian. Hal ini didukung oleh beberapa faktor, yaitu: pertama, dia mempunyai banyak waktu karena ketergantungan beban hidup semakin ringan, anak-anak sudah dewasa dan mempunyai penghasilan sendiri. Kedua, dalam usia ini, mereka tidak lagi berpikir secara kontem platif. $^{24}$

Pada sisi lain, R. F. M. Suling berpendapat bahwa perubahan pemikiran ke arah kontemplatif dapat juga menjadi suatu masalah baru atau beban yang menekan para lanjut usia itu sendiri.

Masa lanjut usia juga sering mendorong perkembangan sikap keagamaan tersebut menjadi lebih dramatis, sikap dan pandangan ini dapat menjadi tertekan dan depresi. Tetapi sebaliknya, dapat juga terjadi lanjut usia dapat mengembangkan sikap lebih berani. Sering kurang mengambil perhitungan duniawi, pada fase usia lanjut dapat dengan berani dikemukan. ${ }^{25}$

Jadi, ketika seseorang memasuki masa lanjut usia ada perubahan yang menyolok dalam masalah rohani mereka. Sikap pasif dan terkesan tidak peduli terhadap perkara perubahan pola pikir. Mereka seperti baru menyadari bahwa hidup bukan hanya perkara fisik semata, ada hal yang terlupakan dan baru terfikir ketika mereka tidak aktif lagi bekerja.

22 Ibid.

23 Hurlock, Psikologi ..., 401

24 Hasil Wawancara dengan Pendeta Agus Wijanto, Gembala Jemaat GKI Cinere.

25 Suling, Pedoman Praktis ..., hlm. 15 


\section{Masalah-Masalah Yang Dihadapi Lanjut Usia}

\section{Rasa kesepian}

Kesepian adalah kesadaran pedih bahwa seseorang kurang memiliki hubungan dekat dan berarti dengan orang lain. Kekurangan tersebut menyebabkan kekosongan, kesedihan, pengasingan diri bahkan keputusasaan. ${ }^{26}$ Rasa Kesepian membawa dampak negatif pada diri seseorang.Sebenarnya perasaan kesepian bukan hanya dirasakan oleh orangorang tertentu saja, tetapi kesepian dapat dialami setiap orang, kapan dan dimana saja. W. S. Hulme mengatakan bahwa:

Kesepian adalah suatu derita yang menekan banyak orang bukan saja mereka yang tinggal jauh dari pasar, jalan yang ramai atau kampung yang berjubel-jubel. Korbannya bukan hanya mereka yang tidak mempunyai keluarga atau teman pekerjaan atau suami dan isteri. Kesepian dapat saja menyusup ke dalam lubuk hati kita semua yang berada di tengah-tengah kesibukan dan keramaian sepanjang hari.

Dalam konteks lanjut usia, bagi kebanyakan orang, memasuki usia lanjut itu berarti menghadapi kesepian.Hal-hal tersebut menjadi masalah bagi lanjut usia karena mereka merasakan hidup sendiri. Kesepian juga disebabkan karena keterpisahan dari orang lain khususnya dengan anak-anak yang telah terpencar untuk membangun rumah tangga mereka sendiri atau karena ditinggalkan oleh orang yang dikasihi. ${ }^{27}$

Jadi, kesepian yang dihadapi oleh lanjut usia sangat berbeda dan kompleks. Mereka dirongrong kesepian bukan hanya karena faktor diri-sendiri tetapi juga oleh karena kondisi lingkungan dan keluarganya.

\section{Perasaan Tertolak}

Perasaan tertolak atau ditolak dalam lingkungan dimana seseorang berada merupakan sesuatu yang menyakitkan. ${ }^{28}$

Derek Prince memberikan pengertian "perasaan tertolak," sebagai berikut:

Yang dimaksud disini ialah suasana hati atau perasaan batiniah seseorang yang bertolak yaitu adanya kesan seperti kurang disenangi atau diusir/dikucilkan; atau perasaan kurang dihargai atau tidak masuk hitungan, merasa diperlakukan bukan sebagai sesama warga, melainkan

26 Charles G. Ward, Buku Pegangan Pelayanan (Jakarta: Persekutuan Pembaca Alkitab, 1984), hlm. 124.

27 Hasil Wawancara dengan Ibu Rorma Boru Sihombing, Jemaat Lanjut usia GPIN "Bukit Asam" Tanjung Enim

28 Peter Salim, Kamus Bahasa Indonesia Kontemporer (Jakarta: Modern Englih Press, 1991), hlm. 1601 
seperti orang luar yang boleh melihat ke dalam, tetapi tidak boleh masuk. $^{29}$

Ternyata perasaan tertolak atau ditolak merupakan salah satu masalah yang dihadapi lanjut usia. Perasaan tertolak yang dialami lanjut lanjut usia tidak terlepas dari kondisi fisiknya yang menurun sehingga mereka tidak dapat lagi melakukan suatu pekerjaan dengan baik.

\section{Hilangnya Harga Diri}

Masalah emosi yang umum bagi para lanjut usia adalah hilangnya harga diri. Mereka tidak ingin dianggap orang lain sebagai orang yang tidak berguna lagi. oleh karena itu mereka menjadi begitu sensitif dengan masalah penghormatan dan penghargaan.Sue Burnham mengatakan:

Secara terperinci rasa harga diri anda terletak pada sejauh mana anda merasa dihargai, berguna dan mampu. Perasaan ini pada dasarnya berasal dari berbagai tanggapan yang anda terima dalam hubungan yang akrab dengan orang lain, dimulai dari hubungan anda denga orang tua, serta penerimaan mereka terhadap anda. ${ }^{30}$

Hal-hal yang disebut oleh Burnham dialami oleh para lanjut usia. Karena menurunnya kemampuan untuk melakukan suatu pekerjaan yang bermanfaat, membuat mereka harus tinggal di rumah, sehingga mereka merasa tidak berguna lagi, baik untuk keluarga maupun untuk masyarakat.

\section{Hilangnya Teman Hidup}

Kehilangan salah satu pasangan hidup merupakan suatu peristiwa yang sangat menyedihkan dan menakutkan bagi para lanjut usia. Dukacita ini adalah satu derita emosional yang sangat menusuk disebabkan oleh kematian orang yang dikasihi. Derita ini dapat berupa kesedihan yang amat memilukan, penderitaan dan kesesakan yang mengakibatkan tangisan dan Jeritan yang pilu, dan juga suasana yang sepi dan sedih. ${ }^{31}$ Mereka kehilangan tempat berbagi suka dan duka sehingga akan dirasa sebagai kehilangan segala-galanya. Sungguh satu perpisahan yang berat, merasa tidak mempunyai apa-apa lagi, seperti kehilangan bagian dari dirinya sendiri. ${ }^{32}$ Garry Collins mengatakan bahwa:

Dukacita merupakan beban perasaan yang sulit ditanggung, meskipun itu merupakan kematian setelah menderita sakit lama, bahkan bagi

29 Derek Prince, Rasa Tertolak (Jakarta: YPI Imanuel, 1994), hlm. 5

30 Sue Burnham, Emosi Dalam Kehidupan (Jakarta: BPK Gunung Mulia, 1994), hlm. 13.

31 Wright, Konseling ..., hlm. 152

32 Hasil Wawancara dengan Lie Jin Fozk, Jemaat Lanjut Usia GMI "Nafiri Sion" Muara Enim. 22 Januari 2000. 
orang-orang Kristen yang sudah memiliki jaminan kebangkitan yang akan datang. Orang-orang yang berdukacita biasanya mengalami beberapa macam pengalaman emosi seperti gelisah, takut, kesepian, kemarahan, kebingungan, kecil hati, bahkan keputusasaan pada saat orang yang dikasihinya meninggalkannya untuk selama-lamanya. ${ }^{33}$

Dengan demikian, kehilangan teman hidup pada masa tua merupakan suatu pergumulan yang berat bagi manusia. Oleh karena itu banyak yang menjadi stres dan akhirnya kehilangan semangat hidup.

\section{Takut Menghadapi Maut}

Perasaan takut menghadapi kematian bukan hanya dirasakan oleh lanjut usia, tetapi juga dihadapi oleh semua orang. Ketakutan menghadapi kematian merupakan hal yang wajar dan manusiawi. Richard L. Margon mengatakan:

Ketakutan akan kematian adalah dasar dari seluruh keprihatinan. Suatu kebohongan kalau kita mengatakan bahwa kita tidak takut mati. Takut mati adalah manusiawi. Mencintai hidup berarti berharap dan tidak ingin meninggalkan kehidupan. Semua orang pada dasarnya takut mati. $^{34}$

Hal ini membuat para lanjut usia cenderung untuk lebih berkosentrasi pada masalah kematian, walau para lanjut usia seringkali merasa takut menghadapi kematian karena ketidak pastian. ${ }^{35}$ Kematian memisahkan mereka dari segala sesuatu yang selama ini dekat dengan dirinya. ${ }^{36}$

Memang kematian dapat terjadi suatu pengalaman yang suram dan menakutkan, terutama bagi mereka yang belum pernah benar-benar siap untuk memasuki masa akhir dari kehidupan mereka atau belum memiliki iman yang cukup untuk menghadapi kematian.

\section{UPAYA DARI GEREJA}

\section{Pengembangan Pelayanan kategorial Lanjut Usia}

\section{a. Dasar Pelayanan}

Pelayanan terhadap jemaat lanjut usia dilakukan atas dasar Firman Allah. Firman yang adalah kekuatan Allah yang bermanfaat untuk mengajar,

33 Gary R. Collins, Konseling Kristen Yang Efektif (Malang: SAAT, 1989), hlm. 169

34 Richard L. Margon, Tetap Ceria Di Usia Senja (Jakarta: BPK. Gunung Mulia, 1998), hlm. 78

35 Hurlock, Psikologi ..., hlm. 402.

36 Ruth Kopp, Ketika Kekasih Mendekati Ajal (Jakarta: BPK. Gunung Mulia, 1992), hlm. 5 
untuk menyatakan kesalahan, untuk memperbaiki kelakuan dan untuk mendidik orang dalam kebenaran (II Tim. 3:16).Oleh sebab itu para lanjut usia dalam gereja perlu menerima dan memahami kebenaran-kebenaran ilahi yang akan menguatkan iman mereka di hari tuanya. Sesungguhnya dalam saat lanjut usia ini mereka membutuhkan bimbingan firman Allah melewati hari-hari tuanya yang sarat dengan pergumulan (Maz. 119:105).

Dalam Matius 28:19-20 dikatakan, "Karena itu pergilah, jadikanlah, jadikan semua bangsa murid-Ku..." Amanat agung merupakan keharusan memuridkan.

Kemudian dasar selanjutnya ialah kasih Allah. Allah bukan hanya mengasihi tetapi Allah juga kasih. Kasih Allah kepada orang yang di dalam Kristus sama seperti kasihNya kepada Kristus sendiri (Yoh. 17:23). Allah mengasihi manusia sebelum mereka mengasihi Kristus, yaitu sebelum orang percaya ada dalam Kristus. Allah mengasihi segenap dunia dan setiap orang di dalam dunia ini (Yoh. 3:16; I Tim. 2:4; II Pet. 3:9). ${ }^{37}$

Belaskasihan Allah kepada manusia bukan baru dimulai di hati Yesus ketika Ia datang ke dalam dunia melainkan telah dimulai dari hati Allah sendiri. Ketika manusia jatuh ke dalam dosa (Kej. 3), mengakibatkan hati Allah digerakkan dengan penuh kasih kepada Adam dan Hawa, di mana Allah datang mencari mereka, ketika manusia itu malu dan bersembunyi karena keberdosaannya. Petrus Octavianus menjelaskan demikian:

Dalam Kejadian 3:15, kasih Allah dinyatakan sebagai satu janji, “... dari benih perempuan akan datang Mesias yang akan membebaskan manusia dari dosa. Benih perempuan yaitu Mesias akan melawan benih ular yakni iblis. Maka sejak Kejadian 3 sampai di Golgota sejarah dunia keselamatan terarah kepada salib Yesus Kristus. Kasih yang telah menggerakkan hati Allah untuk Adam dan Hawa menuntut pengorbanan. Kasih Allah adalah kasih yang mencapai seluruh dunia. ${ }^{38}$

Kasih Allah merupakan salah satu kenyataan yang besar yang terdapat di alam semesta ini, suatu tiang yang merupakan sandaran harapan dunia.

\section{b. Alasan Pelayanan}

Dengan meningkatnya laju pertumbuhan dan perkembangan penduduk, maka gerejapun ikut menunjukkan perkembangan, baik secara kualitas maupun kuantitas. Oleh karena itu gereja membutuhkan bentuk-bentuk pelayanan kategorial untuk menjawab dan memenuhi kebutuhan jemaat yang semakin bervariasi.

37 J. Wesley Brill, Dasar Yang Teguh (Bandung: Kalam Hidup, 1994), hlm. 54

38 Petrus Octavianus, "Kasih Allah Sebagai Daya Penggerak Misi” dalam Misi Kasih Yang Mencari (Batu-Malang: Dept. Literatur, 1985), hlm. 143. 
Permasalahn-permasalahan yang dihadapi warga gereja berbeda-beda. Permasalahan anak-anak berbeda dengan permasalahan remaja, begitu juga permasalahan jemaat dewasa berbeda dengan permasalahan jemaat lanjut usia. Sejalan dengan itu, Wibisono mengatakan:

Setiap tahap dalam siklus kehidupan manusia nampak-nya memiliki ciri yang agak khas, yaang permasalahan umum yang khas, yang membawa permasalahan umum yang khas pula: masa bayi, masa kanak-kanak, masa remaja, masa dewasa muda, masa usia pertengahan dan lanjut usia. ${ }^{39}$

Secara khusus lanjut usia mereka diperhadapkan dengan masalahmasalah yang paling rumit, sehingga membutuhkan pelayanan khusus/kategorial.Di samping itu, pelayanan khusus/kategorial perlu dikembangkan oleh gereja untuk mengantisipasi laju perkembangan jumlah lanjut usia yang terus meningkat.Karena itu pembinaan jemaat dimulai dari sekolah minggu (3-11 thn.), remaja (12-17 thn.), pemuda (18-25 thn.), dewasa (25-29 thn.) dan lanjut usia (60 thn. keatas). ${ }^{40}$

\section{c. Tujuan Pelayanan}

Gereja harus mempunyai tujuan yang jelas dalam pelayanannya. Pengembangan pelayanan kategorial terhadap jemaat lanjut usia bertujuan mempersiapkan dan meneguhkan iman mereka sampai akhirnya Tuhan memanggil mereka.Di samping itu dengan pelayanan kategorial, jemaat lanjut usia dapat dilibatkan dalam berbagai pelayanan gerejawi juga penginjilan, khususnya sebagai pendoa syafaat. Mereka memiliki banyak waktu luang di rumah, sehingga mereka dapat dimotivasi menjadi pendoa-pendoa syafaat untuk para pemimpin atau Gembala Jemaat teristimewa untuk penginjilan diseluruh muka bumi. ${ }^{41}$

Para lanjut usia sering merasa kurang dihargai ditengah kesibukan jemaat. Mereka merasa tidak berharga oleh karena kenyataan bahwa pelayanan di gereja telah ditengani oleh jemaat dewasa dan pemuda yang lebih gesit dan berpotensi. Karena itu lewat pengembangan pelayanan kategorial bagi para lanjut usia, akan sangat menolong.Sehubungan dengan hal itu, Ralp Rggs mengatakan:

Pertemuan dan kebaktian untuk berbagai tingkat umur dan kelompok serta departemen gereja harus diselenggarakan. Semua itu memerlukan pemimpian dan menemukan orang-orang yang sanggup melayani

39 Ibid. Selatan.

40 Hasil Wawancara dengan Pdt. Agus Wijanto, Gembala Jemaat GKI Cinere, Jakarta 193. 
dalam berbagai fungsi dan memakai mereka untuk melaksanakan pelayanan. $^{42}$

Dengan demikian, pelayanan terhadap jemaat lanjut usia selain bertujuan untuk menolong mereka bertumbuh dalam kerohanian tetapi juga melibatkan mereka dalam pelayanan.

\section{d. Hambatan Dalam Pelayanan}

Dalam mengembangkan pelayanan terhadap jemaat lanjut usia tidak terlepas dari tantangan dan pergumulan yang menjadi hambatan. Hambatan tersebut dapat saja berasal dari hamba Tuhan sandiri dan atau dari jemaat lanjut usia yang ada.

Oleh karena itu, pelayanan terhadap jemaat lanjut usia membutuhkan pelayanan khusus.. Hambatan lainnya yaitu menyangkut jemaat yang lanjut usia sendiri. Kondisi fisik mereka yang semakin melemah dapat menjadi hambatan dalam pelayanan, daya tangkap/nalar dan daya ingat jemaat lanjut usia yang semakin menurun, sehingga firman Tuhan yang disampaikan seringkali sulit dimengerti atau mereka cepat sekali lupa pada firman Tuhan yang pernah mereka dengar. ${ }^{43}$

Hambatan yang lainnya ialah jumlah jemaat yang masuk kategori lanjut usia itu sangat sedikit dalam satu gereja. Hal tersebut membuat gereja kurang memperhatikan pelayanan terhadap mereka. ${ }^{44}$ Jadi, dari segi jemaat lanjut usia itu sendiri hambatannya ialah kondisi fisik mereka yang terus menerus lemah, kondisi otak dan nalar mereka terus menurun juga jumlah yang sangat sedikit dalam satu jemaat/gereja.

\section{Metode Pelayanan}

\section{A. Pembinaan Rohani}

Pembinaan rohani oleh gereja adalah pembinaan warga jemaat yang berpusat Kristus. Hal tersebut didasarkan pada pengajaran Alkitab, dan merupakan proses untuk menghubungkan kehidupan jemaat yang lanjut usia dengan Firman Tuhan, membimbing dan mendewasakan dalam Kristus melalui kuasa Roh Kudus (11 Ptr. 3 :18). Selain itu pembinaan rohani yang dimaksud ialah suatu upaya untuk memperlengkapi anggota jemaat yang sebagai anggota tubuh Kristus (Ef. 4:11-16).Dengan demikian, jemaat lanjut usia juga memerlukan pembinaan rohani tersebut para lanjut usia dapat dituntun kepada keyakinan akan keselamatan yang kokoh sehingga mereka

42 Ralp. M. Ringgs, Gembala Sidang Yang Berhasil (Malang: Penerbit Gandum Mas, 1984), hlm. 76

43 Hasil Wawancara dengan Pdt. J. Damanik, S. Th.

44 Ibid 
hidup dalam penyerahan diri.Dalam pembinaan rohani terhadap jemaat lanjut usia ada beberapa metode selayaknya dikembangkan oleh gereja yaitu:

\section{1) Perkunjungan}

Istilah perkunjugan dalam bahasa Inggris yaitu "visitation" dari kata kerja "to visit" yang artinya kunjungan/mengunjungi, datang untuk bertemu, berkunjung. Dengan demikian perkunjungan berarti datang untuk bertemu seseorang dengan maksud tertentu, atau juga perkunjungan karena tugas dan tanggung jawab. ${ }^{45}$ Dalam kegiatan pelayanan gerejawi, istilah yang dipakai yaitu "perkunjungan rumah tangga". Bons Storm mengistilahkannya sebagai "perkunjugan pastoral" yaitu meliputi perkunjungan orang sakit, orang dalam penjara atau siapa saja yang hidup di luar suatu rumah tangga seperti orangorang terlantar atau tuna wisma. ${ }^{46} \mathrm{Hal}$ ini berarti kegiatan perkunjugan sudah tidak asing dalam pelayanan gerejawi, bahkan merupakan suatu kewajiban hamba Tuhan termasuk para gembala jemaat.

Di samping itu, Tasdik mencatat ungkapan Richard Cobot tentang pentingnya perkunjungan oleh pemimpin gereja sebagai berikut:

Pemimpin-pemimpin agama yang besar sepanjang masa adalah mereka yang mendengarkan sabda Tuhan pada satu pihak dan mendengarkan suara orang banyak pada pihak lain. Gereja protestan harus memperbaharui hubungannya dan perhatiannya dalam memelihara jiwa-jiwa. Pemimpin harus turun dari mimbar dan mencari mereka yang membutuhkan, dan harus siap mendengar. ${ }^{47}$

Jadi, seorang hamba Tuhan atau Gembala Jemaat bukan hanya bertugas untuk bertugas untuk menyampaikan firman Tuhan dari mimbar saja, tetapi juga dituntut untuk mengatur waktu mengampuni jemaat, terlebih terhadap mereka yang membutuhkan perhatian khusus dan pertolongan.Pelayanan perkunjungan akan membangkitkan semangat para lanjut usia, karena mereka akan merasa dihargai dan dihargai dan dikasihi. ${ }^{48}$ Di samping itu mereka memang butuh perhatian dan perlu dirangkul. ${ }^{49}$ Bagaimanapun ketika dikunjungi, secara tidak lansung dan tidak disadari adalah satu tindakan praktis dari hamba-hamba Tuhan untuk mengusir rasa kesepian yang menjadi pergumulan jemaat lanjut usia.Kehadiran orang lain memberi kesukaan

45 Abineno, Penggembalaan (Jakarta: BPK Gunung Mulia, 1967). 37. hlm. 69.

46 M. Bons Storm, Apakah Penggembalaan itu? (Jakarta: BPK Gunung Mulia, 1988), hlm. 82 .

R. Tasdik, Penginjilan dan Penggembalaan ( Yogyakarta: Duta Wacana, 1979),

48 Kenneth L. Gibble, "Mempersiapkan Jemaat Untuk Suatu Kunjungan Pastoral," Kepemimpinan, XV (Januari, 1989), 27-28.

49 Hasil Wawancara dengan A. R. Sri Sulastri, Jemaat Lanjut Usia GPIN "Bukit Asam” Tanjung Enim. 22 Januari 2000. 
tersendiri buat mereka, karena mereka mendapat teman bicara dan bertukar pikiran atau cerita. Bagaimanapun setiap orang ingin didengar, sebagai tanda dihargai dan dihormati.

\section{2) Konseling}

Pelayanan konseling merupakan salah satu bentuk pelayanan yang sangat penting dalam memenuhi tugas dan tanggung jawab gereja demi pembinaan dan pendewasaan warga jemaatnya.Jika dilihat dari segi tanggung jawab geraja dalam pelaksanaan tugas dan panggilannya, maka bentuk pelayanan yang efektif dalam upaya menyelesaikan masalah dan pergumulan pribadi lanjut usia. ${ }^{50}$

Istilah "konseling" berasal dari kata kerja "Counsel" yang berarti menasihati, menyarankan, mendorong, menganjurkan, sedangkan "conselor" berarti penasehat, pengacara, pengasuh anak-anak dalam kemah, sedangkan konseling adalah hubungan timbal balik di antar dua individu, yaitu konselor yang berusaha menolong dan konseling yang membutuhkan pengertian untuk mengatasi persolan yang dihadapi ${ }^{51}$ Jadi pelayanan konseling berarti memberikan nasihat, saran dan dorongan kepada orang lain. Oleh karena itu pelayanan konseling merupakan salah satu pelayanan yang sangat penting dalam memenuhi tugas dan tanggung jawab gereja dalam pembinaan dan pendewasaan rohani warga jemaat lanjut usia. Ada beberapa bentuk pelayanan konseling yang harus dilakukan gereja yaitu: pertama, Konseling Evangelistis dan Peneguhan. Dalam hubungan dengan para lanjut usia, konseling evangelistis dan peneguhan adalah upaya pemeriksaan ulang keyakinan keselamatan dan keteguhan iman. Kedua, konseling kelompok. Salah satu ciri khas orang lanjut usia adalah cenderung untuk berteman dan hidup berkelompok dengan sesama lanjut usia. Hal tersebut mungkin terjadi karena adanya persamaan minat juga perasaan. Oleh sebab itu konseling kelompok perlu dan cocok dilaksanakan dalam pelayanan terhadap jemaat lanjut usia.Dengan demikian terlihat bahwa konseling kelompok memang sangat bermanfaat bagi pembinaan jemaat termasuk lanjut usia, dimana jemaat lanjut usia dapat membagikan permasalahan dan pengalaman mereka mengatasi berbagai pergumulan sehubungan dengan usia tua, sehingga dapat mereka akan saling menolong dan saling menguatkan satu dengan yang lainnya.

Ketiga, Konseling Didaktis. Konseling Didaktis merupakan bentuk konseling yang bersifat mendidik atau mengajar. Dalam hal ini bentuk dalam pelayanan terhadap jemaat lanjut usia difokuskan pada penyampaian firman Tuhan berupa pengajaran yang bersifat mendidik, dalam kaitan dengan doktrin juga pemahaman yang keliru bahkan bertentangan dengan kebenaran firman

50 Jesias Palandi, “Cristian Conseling Cross Cullturally dan Penerapannya Dalam Pelayanan Konseling Terhadap Orang Toraja Di Surabaya " Tesis (Malang: Institut Injil Indonesia, 1991), hlm 420.

51 Gary R. Collins, Konseling Kristen Yang Efektif (Malang: SAAT, 1989), hlm. 59. 
Tuhan. Melalui konseling didaktis pemahaman yang salah ini dapat diluruskan oleh hamba-hamba Tuhan melalui pengajaran-pengajaran yang sesuai dengan Firman Tuhan.

\section{3) Ibadah/Persekutuan Lanjut Usia}

Ibadah/persekutuan merupakan ketetapan Tuhan Yesus yang harus dilakukan. Karena setiap orang percaya dipanggil masuk dalam persekutuan dengan Tuhan Yesus. Riedel mengatakan, "Di dalam surat Yahya yang pertama kerap kali ditemui perkara persekutuan itu”. Barang siapa yang telah menjadi orang Kristen, ia itu hidup di dalam persekutuan Allah. persekutuan dengan Bapa dan dengan Yesus Kristus, anak-Nya itu (1 Yoh. 1:3,6).” Dengan demikian pembentukan ibadah/persekutuan lanjut usia adalah merupakan satu langkah tepat dalam upaya pembinaan rohani mereka. Dalam ibadah/persekutuan khusus lanjut usia, mereka memperoleh kesempatan untuk saling menguatkan, saling menasihati, saling membagi pengalaman dan menghibur di antara mereka, agar semakin kuat di dalam Tuhan sampai akhir hayatnya. ${ }^{52}$

Dalam ibadah atau persekutuan khusus untuk lanjut usia diadakan beberapa kegiatan yang bervariasi dan sederhana disesuaikan dengan daya serap lanjut usia dan kemampuan serta kondisi fisik mereka yang semakin melemah, seperti khotbah/renungan, pemahaman Alkitab dengan topik yang sesuai dengan kebutuhan mereka dan berikan kesempatan kesaksian.

\section{4) Katekisasi Persiapan Kematian}

Istilah "katekisasi" atau "katekese" berasal dari kata kerja Yunani "katakhein" yang berarti memberitakan, mengajarkan dan memberitakan pengajaran. Namun yang paling menonjol dari pengertian "katakhein" adalah "mengajar" yakni mengajar atau membimbing agar orang melakukan apa yang diajarkan kepadanya. ${ }^{53}$ Kata ini juga diterjemahkan dengan "mengajar" secara lisan, memberitahukan." Dalam tugas dan pelayanan, katekisasi dianggap sebagai salah satu bagian dalam gereja yang penting. ${ }^{54}$

Jadi, katekisasi merupakan pelajaran atau pembinaan dasar untuk membawa orang percaya kepada pengenalan akan Allah dan peneguhan iman.Katekisasi lanjut usia bertujuan untuk mempersiapkan para lanjut usia menghadapi kematiannya. oleh karena mereka mengetahui dengan pasti ke mana mereka akan pergi setelah mereka mati, seperti kata Paulus, "Aku akan

52 Hasil Wawancara dengan Ibu Sumarmi, Staf Pembina STT, Ebenhaezer Tanjung Enim.

53 J. L. Ch. Abineno, Buku Katekisasi Perjanjian Baru (Jakarta: BPK Gunung Mulia, 1987), hlm. 5-7 
pergi dan diam bersama-sama dengan Kristus. Karena bagiku hidup adalah Kristus dan mati adalah keuntungan" (Filipi 1:23, 21).

\section{5) Melibatkan Lanjut Usia Dalam Pelayanan}

Bagaimanapun juga sebagai orang percaya, para jemaat lanjut usia harus hidup di dalam persekutuan. Oleh karena itu para lanjut usia juga harus kesempatan untuk melibatkan diri dalam pelayanan. Hamba Tuhan dan Gembala Jemaat pada sisi ini mempunyai tugas untuk melatih serta mengembangkan bakat dan karunia yang diberikan Tuhan kepada setiap jemaat termasuk para jemaat lanjut usia. ${ }^{55}$ Dengan demikian mereka tidak hidup untuk diri sendiri melainkan untuk sesama dan untuk kemulian Tuhan (Flp. 2:4). Hal tersebut juga merupakan suatu terapi yang baik untuk melawan gejolak emosi yang menimbulkan sikap egois yang "dilumrahkan" untuk orang pada tahap usia lanjut. Menurut Brubaker:

Gereja dapat memperoleh mamfaat karena kenyataannya bahwa orangorang lanjut usia sering mempunyai banyak waktu luang sehingga dapat membantu dalam jabatan kepemimpinan, perkunjungan, pengajaran dan penyuluhan (Maz. 71:18; Titus 2:1-5). Ia dapat melaksanakan pelayanan khusus dengan berdoa dan menulis surat atau menyediakan anak-anak. Lanjut usia dapat membantu dalam kebaktian pertengahan minggu, pekan pendidikan rohani anak-anak, kamp remaja. $^{56}$

Keterlibatan mereka dalam pelayanan dapat dimulai dalam persekutuan/ibadah lanjut usia sendiri, misalnya mereka diberi kesempatan menjadi liturgos, pemimpin doa, ketua kelompok diskusi, kolekoten atau juga pemain musik. Melalui keterlibatan dalam pelayanan seperti itu, mereka akan menyadari bahwa mereka masih diperlukan dalam pekerjaan Tuhan.

\section{6) Ibadah Perayaan Hari Lanjut Usia}

Dalam perhatiannya terhadap penduduk lanjut usia sebagai warga negara yang memiliki pengalaman luas dan berharga yang dapat diteladani oleh generasi penerusnya, maka pemerintah telah memilih dan menetapkan tanggal 29 Mei sebagai Hari Lanjut Usia Nasional. ${ }^{57}$ Dengan demikian gereja selaku bagian dari komponen bangsa yang juga peduli terhadap kehadiran para usia di tengah-tengah jemaat dapat memakai momentum ini. Ibadah perayaan Hari Lanjut Usia dapat diadakan di gereja-gereja sebagai bukti kepedulian gereja. Pada hari tersebut merupakan suatu kebahagian tersendiri bagi para

\footnotetext{
55 Larry Lea, Panggilan Tertinggi (Jakarta: YPI Imanuel, 1991), hlm. 75

56 Brubaker, Memahami Sesama ..., hlm. 123

57 Pelembagaan Lanjut Usia..., hlm. 15
} 
lanjut usia oleh karena pada hari itu semua jemaat akan memberi salam dan perhatian khusus bagi mereka.

Kegiatan sepanjang hari itu dapat difokuskan disekitar topik lanjut usia, seperti mengunjungi panti-panti penampungan jompo dan lanjut usia terdekat pada pagi hari, sore harinya kegiatannya diadakan di gereja misalnya lomba antar lanjut usia, jalan sore dan lain-lain. Akhirnya secara puncak pada hari itu adalah ibadah Hari lanjut usia.

\section{B. Pembinaan Fisik}

\section{1) Hasta Karya}

Dalam kaitannya dengan tugas pelayan terhadap warga jemaat lanjut usia, hamba Tuhan perlu memikirkan strategi pelayanan yang mendasar dan efektif, menyangkut keberadaan mereka secara fisik. Salah satu kegiatan yang dapat dilakukan oleh gereja sebagai wadah penyaluran hobby dan ketrampilan lanjut usia, sekaligus untuk mengisi waktu luang mereka ialah melalui harta karya.Hasta karya yang dapat dibuat oleh para lanjut usia sebagai kegiatan bersama-sama, seperti membuat tikar, sulaman, kotak surat, sapu tangan, sarung Alkitab, pembatas kitab, dan sebagainya. Dengan melihat hasil karyanya, mereka akan terdorong dan kembali memiliki semangat hidup. Pada waktu itu mereka akan sadar bahwa masih ada yang dapat diperbuat, dan itu berguna bagi orang lain. Mereka akan kembali percaya diri, dan sangat menolong mereka.

\section{2) Rekreasi}

Reakreasi adalah suatu bentuk kegiatan yang bertujuan mengembalikan kesegaran yang menyelutuh terhadap eksistensi manusia. Jika demikian maka reakreasi tidak hanya diadakan untuk golongan untuk umur tertentu saja tetapi cocok untuk segala umur, termasuk didalamnya para lanjut usia. Vera Indrasuwita mengatakan:

Manusia lanjut usia tentu saja membutuhkan rekreasi, ikut piknik untuk menyegarkan mental dan fisiknya. Sebab tidak jarang mereka yang sudah pensiun merasa kesepian. Meskipun mereka beranak cucuk, namun perasaannya akan lain bila mereka bertemu dengan kawankawan sebaya dan sama-sama gembira. ${ }^{58}$

Dengan demikian reakreasi sangat bermanfaat bagi para lanjut usia sehingga harus dimasukkan dalam program pelayanan terhadap mereka. Pelaksanaan kegiatan reakreasi untuk jemaat lanjut usia harus memiliki nilainilai Kristiani (Kol. 3:14), sehingga aktifitas tersebut tidak hanya sekedar menimbulkan atau memenuhi rasa gembira dan segar, tetapi mengantar mereka

58 Vera Indrasuwita, "Lansia Perlu Rekreasi Segarkan Mental” Suara Pembaharuan (Jakarta) 4 juni 1996 
semakin menghargai dan menerima diri sendiri sebagaimana adanya, serta menyadari bahwa mereka berharga di mata Tuhan.

\section{3) Pelayanan Kesehatan}

Penyakit dan ganguan kesehatan pada lanjut usia merupakan bukti bahwa kondisi tubuhnya semakin merosot, sehingga kekuatan fisik semakin menurun. Dengan mengacu pada program pemerintah mewujudkan masyarakat adil dan makmur berdasarkan Pancasila dan UUD 1945 yang diselenggarakan menurut GBHN dan misi pembangunan kesehatan di tas, maka dibentuk suatu pelayanan bersama dari yayasan-yayasan Kristen yang diberi nama "Persatuan pelayanan Kristen untuk kesehatan di Indonesia (PELKESI)". 59 Pelayanan ini adalah pelayanan yang holistik yaitu pelayanan yang bertitik tolak pada pikir dan memandang manusia secara utuh di dalam semua aspek: baik upaya-upaya pendekatan, peningkatan, pencegahan, pengobatan dan pemulihan.Hal lain yang dapat diadakan oleh gereja dalam hubungan dengan peningkatan kesehatan para lanjut usia, ialah dengan mengadakan olah raga bersama. Olah raga juga berfungsi sebagai alat untuk memelihara dan meningkatkan kesengsaran jasmani. ${ }^{60}$

\section{4) Pelayanan Diakonia}

Pelayanan Diakonia atau pelayanan sosial merupakan salah satu tugas dan panggilan gereja yang mau tidak mau harus dikerjakan harus dikerjakan.Istilah diakonos, yang berarti attendance (as a servant etc), aid (official), service. Abineno menjelaskan kata "diakonia" demikian:

Kata Yunani "Diakonia" biasa dipakai untuk pelayanan meja makan, pelayanan pribadi kepada orang lain. Pelayanan ini terutama dilakukan oleh hamba-hamba atau wanita-wanita, dan dianggap sebagai suatu pekerjaan yang hina. Orang-orang mereka atau terpelajar tidak melayani di meja makan tetapi justru dilayani oleh pelayan-pelayan. ${ }^{61}$

Dalam Perkembangannya, secara khusus dalam PB penggunaannya istilah "diakonia" menjadi lebih umum, misalnya untuk hamba-hamba raja (Mat. 22:13), dalam surat Kol. 1:7, 23, 25, Epafras disebut Paulus sebagai pelayan Kristus sedangkan Paulus sendiri adalah pelayan Injil, pelayanan jemaat.Dengan demikian istilah "diakonia" dalam PB dikenakan khusus kepada pekerjaan penginjilan dan kerja penggembalaan. Oleh karena itu pelayanan Marta kepada Yesus beserta para murid (Luk. 10:40) dan pelayanan

59 Pasaribu, "Peranan RS/Unit ...", hlm. 58

60 Arma Abdoelah, Olah Raga Untuk Perguruan Tinggi (Yogyakarta: Sustra Hadaya, 1981), hlm. 24

61 J. L. Ch. Abineno, Melayani Dan Beribadah Di Dalam Dunia (Jakarta: BPK Gunung Mulia, 1974), hlm. 44 
mertua Petrus (Mark. 1:31) dikategorikan ke dalam pelayanan diakonia. ${ }^{62}$ Dalam hubungan dengan jemaat lanjut usia, maka gereja tidak hanya memperhatikan pemenuhan kebutuhan rohani saja tetapi juga perlu memperhatikan pemenuhan kebutuhan jasmaninya, seperti makan dan pakaian, pemeliharaan kesehatan dapat diberikan secara teratur. (band. Panti sosial Tresna Werdha). ${ }^{63}$ Oleh karena itu, membutuhkan alokasi dana khusus, biaya operasionalnya cukup besar karena harus memikirkan kehidupan mereka dan transportasi untuk kegiatan-kegiatan rutinnya.

\section{SIMPULAN}

Lanjut usia adalah mereka yang rata-rata telah memasuki usia 60 tahun ke atas. Dalam usia seperti ini setiap orang mengalami perubahan-perubahan yang mengarah pada kemunduran-kemunduran, baik dari segi fisik maupun rohani. Perubahan fisik akan mempengaruhi segi psikologis, sosiologis, dan pneumatologis para lanjut usia, sehingga mereka akan mengalami perasaan rendah diri karena merasa tidak mampu dan tidak berguna lagi.Hal tersebut akan membuat mereka menutup diri, akibatnya mereka merasa kesepian. Masalah ini akan terasa lebih berat lagi oleh karena memang para lanjut usia akan ditinggalkan oleh anak-anak yang telah terpencar ke berbagai tempat untuk membangun rumah tangga sendiri (sidron "sarang kosong").

Dalam keadaan demikian para lanjut usia cenderung untuk berdiam diri di rumah saja, suatu kondisi yang menjadi penyebab timbulnya masalah baru bagi para lanjut usia. Mereka akan menjadi asing bagi linkungan dan dilupakan orang, akibatnya mereka tertolak dan kehilangan harga diri.

Oleh karena itu pelayanan gereja terhadap para lanjut usia haruslah ditempatkan sebagai satu pelayanan kategorial dan serius ditangani oleh pekerja dan hamba Tuhan khusus yang sungguh memahami persoalan atau permasalahan lanjut usia.Pelayanan kategorial tersebut akan membuat gereja terikat secara moril pada penanganan yang serius dan bertanggung jawab terhadap para lanjut usia yang menjadi anggota jemaat. Itu berarti pelayanan kategorial akhirnya memberikan keseimbangan dalam perhatian dan aksi penatalayanan dalam seluruh gerak pelayanan gereja.

62 J. D. Douglas (Peny.), "Diakon" Ensiklopedi Alkitab Masa Kini I, ( Jakarta: Yayasan Komunikasi Bina Kasih/OMF, 1997), hlm. 245

63 Petunjuk Teknis Pelaksanan Pelayanan Kesejahteraan Sosial Lanjut Usia Dalam Panti (Jakarta: Departemen Sosial RI, 1997), hlm. 5-23 


\section{DAFTAR PUSTAKA}

Soetodjo, Edi

1994 "Jangan Menjadikan Lanjut Usia Seperti Tong Sampah", Suara

Pembaharuan Jakarta.

Tobing S. M. Lumban,

1995 Kecerdasan Pada Usia Lanjut dan Manusia Jakarta: Balai Penerbit FKUI

1997 Petunujuk Teknik Pelaksanaan Pelayanan Kesejahteraan Sosial Lanjut Usia Dalam Panti Jakarta: Departemen Sosial RI,

1989. "Masalah Kualitas Hidup Manula", Suara Pembaharuan Jakarta

Wibisono, Sasanto

1991 "Pengaruh Perubahan Fisik Usia Lanjut Pada Aspek Kejiwaan", dalam Mardiono Marsetio, Arjatmo Tjokronegoro, ed., Kelanggengan Usia Lanjut (Jakarta: Fakultas Kedokteran Universitas Indonesia,

SJ, F. Hamma

1988 Krisis Tengah Umur Yogyakarta: Penerbit Kanisius,

Kenny, Janus dan Kenny, Mory

1991 Dari Bayi Sampai Dewasa Jakarta: BPK. Gunung Mulia,

Saparinah Sadli,

1983 Di Atas 40 Tahun Jakarta: Sinar Harapan,

Wright, H. Norman

1993 Konseling Krisis (Malang: Gandum Mas,

Mappriare, Andi

1983 Psikologi Orang Dewasa Surabaya: Usaha Nasional,

Herlambang, S. M.

1997 "Forum Komunikasi Lansia/ Pergeri" Dimasa Depan, "Buletin Gerontologi dan Geriatri XXXI XXXII"

Suenarjo,

1997 "Usia Lanjut Usia Sehat Sejahtera dan Bermamfaat," Buletin

Gerontologi dan Geriatri, XXXI-XXXII 
Suling, R. K. M. dan Pelenkahu, S. S.

1996 Pedoman Praktis bagi Manusia Usia Lanjut Jakarta: BPK Gunung Mulia,

Ward, Charles G

1984 Buku Pegangan Pelayanan Jakarta: Persekutuan Pembaca Alkitab,

Peter Salim,

1991 Kamus Bahasa Indonesia Kontemporer (Jakarta: Modern Englih Press,),

Derek Prince,

1994 Rasa Tertolak Jakarta: YPI Imanuel,

Sue Burnham,

1994 Emosi Dalam Kehidupan Jakarta: BPK Gunung Mulia,

Collins, Gary R.

1989 Konseling Kristen Yang Efektif Malang: SAAT,

Margon, Richard L.

1998 Tetap Ceria Di Usia Senja Jakarta: BPK. Gunung Mulia,

Kopp, Ruth

1992 Ketika Kekasih Mendekati Ajal Jakarta: BPK. Gunung Mulia,

Brill, J. Wesley

1994 Dasar Yang Teguh Bandung: Kalam Hidup,

Petrus Octavianus,

1985 "Kasih Allah Sebagai Daya Penggerak Misi” dalam Misi Kasih Yang Mencari (Batu-Malang: Dept. Literatur,

Wagner, C. Peter

1997 Berdoa Dengan Penuh Kuasa Jakarta: Nafiri Gabriel,

Ralp. M. Ringgs,

1984 Gembala Sidang Yang Berhasil Malang: Penerbit Gandum Mas,

Abineno, J. L. Ch.

1967 Penggembalaan Jakarta: BPK Gunung Mulia, 
Storm, M. Bons

1988 Apakah Penggembalaan itu? Jakarta: BPK Gunung Mulia,

Tasdik, R.

1979 Penginjilan dan Penggembalaan Yogyakarta: Duta Wacana.

Gibble, Kenneth L.

1989 "Mempersiapkan Jemaat Untuk Suatu Kunjungan Pastoral, ” Kepemimpinan, XV

Jesias Palandi,

1991 "Cristian Conseling Cross Cullturally dan Penerapannya Dalam Pelayanan Konseling Terhadap Orang Toraja Di Surabaya " Tesis Malang: Institut Injil Indonesia.

Gary R. Collins, 1989 Konseling Kristen Yang Efektif Malang: SAAT.

Abineno, J. L. Ch.

1987 Buku Katekisasi Perjanjian Baru Jakarta: BPK Gunung Mulia.

Hauken,

1992 Ensiklopedi Gereja II Jakarta: Yayasan Cipta Loka Caraka.

Lea, Larry

1991 Panggilan Tertinggi Jakarta: YPI Imanuel.

Vera Indrasuwita,

1996 "Lansia Perlu Rekreasi Segarkan Mental” Suara Pembaharuan Jakarta

Arma Abdoelah,

1981 Olah Raga Untuk Perguruan Tinggi Yogyakarta: Sustra Hadaya

Abineno, J. L. Ch.

1974 Melayani Dan Beribadah Di Dalam Dunia Jakarta: BPK Gunung Mulia,

J. D. Douglas (Peny.),

1997 "Diakon" Ensiklopedi Alkitab Masa Kini I, ( Jakarta: Yayasan Komunikasi Bina Kasih/OMF

1997 Petunjuk Teknis Pelaksanan Pelayanan Kesejahteraan Sosial Lanjut Usia Dalam Panti Jakarta: Departemen Sosial RI, 
Missio Ecclesiae, 8(2), Oktober 2019, 93-115

1999 Peranan Pemerintah Dalam Pembinaan Kesejahteraan Sosial Lanjut Usia Jakarta: Departemen Sosial RI.

1998 Pelembagaan Lanjut Usia Dalam Kehidupan Bangsa, (Jakarta: Departemen Sosial RI 